\title{
Effect of Denture Surface Glazing on Denture Plaque Formation
}

\author{
Newton SESMA ${ }^{1}$ \\ Dalva Cruz LAGANÁ ${ }^{1}$ \\ Susana MORIMOTO² \\ Carlos GIL ${ }^{1}$
}

\author{
${ }^{1}$ Department of Prosthodontics, Faculty of Dentistry, University of São Paulo (FOUSP), São Paulo, SP, Brazil \\ ${ }^{2}$ Department of Restorative Dentistry; Faculty of Dentistry, University of São Paulo (FOUSP), São Paulo, SP, Brazil
}

\begin{abstract}
This study evaluated, in vivo, the efficacy of a denture glazing material (Palaseal) in modifying plaque colonization of dentures. Ten subjects were selected and received maxillary temporary partial removable dentures, with complete acrylic palatal coverage. The right half of the fitting surface of the denture bases were glazed with Palaseal, whereas the other half was not glazed. One month after insertion, two fragments of the resin base of all dentures were removed (one from the glazed side and another from the non-glazed side). These samples were prepared and examined by scanning electron microscopy. Three months after insertion, other fragments were obtained and analyzed. Microscopic observation at 1 month revealed that, for all patients, the plaque film was thinner on the treated side in comparison to the non-treated side. However, at the 3-month evaluation, some areas of the glaze showed cracking, and both glazed and non-glazed sides were covered by a dense bacterial plaque film. In conclusion, the findings of this clinical experiment showed that glazing denture's fitting surface did not prevent bacterial colonization, but favored plaque removal while the glaze layer remained intact. After three months, glaze cracks created microretentive areas that increased plaque accumulation.
\end{abstract}

Key Words: denture plaque, denture glaze, scanning electron microscopy.

\section{INTRODUCTION}

The correlation between dental plaque and gingival problems has been well established since the 1960s, thereafter professionals became aware of the importance of plaque control and patients started to get involved in personal daily oral hygiene. Nevertheless, the relationship between denture plaque and oral mucosa diseases has not been widely recognized by dentists and therefore denture wearers have not been well instructed on the importance of denture cleanliness for maintenance of oral health (1).

Denture stomatitis is one of the oral infections associated to the use of dentures. It is a chronic disease characterized by either localized/generalized inflammation or inflammatory papillary hyperplasia that may affect patients wearing complete or partial removable prostheses in one or both dental arches. It may be highly prevalent and hard to treat due to its multifactorial etiology $(2,3)$. The combination of systemic factors, such as nutritional deficiency, diabetes, physical debilitation, immune suppression, and local factors, such as trauma caused by the prosthesis, fungal and bacterial infections and lack of hygiene, can make patients more susceptible to denture stomatitis (4).

The presence of the denture is the triggering local factor for the disease. The denture's fitting surface cannot be mechanically polished and thus presents irregularities and microscopic pores that facilitate bacterial and fungal colonization (5). In patients with poorly balanced occlusion, the denture may cause trauma to the palatal mucosa, which reduces tissue resistance to infection and increases mucosa permeability, contributing to the passage of toxins produced by the microorganisms (6). 
Denture plaque formation is similar to bacterial dental plaque formation and its control is equally important. Emphasis must be on prevention of plaque accumulation together with effective plaque removal measures to avoid denture-related stomatitis (7).

Some glazes have been used for sealing dentures. According to the manufacturers, a glaze would make the acrylic resin surface smoother, decreasing accumulation of residual food and plaque adhesion, and providing improved oral hygiene conditions.

In view of the reduced number of in vivo studies investigating the effectiveness of denture glazing materials, this clinical study was designed to evaluate the effect of glazing denture's fitting surface on bacterial colonization of denture plaque, by means of scanning electron microscopy (SEM).

\section{MATERIAL AND METHODS}

Ten partially edentulous subjects aged 35 to 65 years ( 6 male and 4 female) were selected as voluntaries. Only individuals with few (1 to 3 ) anterior maxillary missing teeth were enrolled in this study. The participants were instructed to wear the dentures all day and night to ensure continuous plaque formation.

Maxillary temporary partial removable dentures were fabricated using heat-polymerized acrylic resin (Clássico; Artigos Odontológicos Clássico Ltda, São Paulo, SP, Brazil), according to the manufacturer's instructions. The dentures were prepared with complete palatal coverage and adapted steel wire clasps for retention, in such a way that bacterial colonization of the fitting surface of the resin bases could be examined microscopically. No polishing of the internal surface was accomplished.

A layer of a light-cured glaze (Palaseal; Heraeus/ Kulzer, Wehrheim, Germany) was applied to the right side of the dentures' fitting surface using a soft brush and light-cured (UNIXS; Heraeus/Kulzer) for 3 min. The left side was not coated with Palaseal (Fig. 1). The prostheses were then adjusted and installed.

The volunteers wearing the dentures followed a standard denture cleansing protocol. They were instructed by a hygienist to clean their prostheses using low-abrasion toothpaste (Colgate; Colgate-Palmolive, São Bernardo do Campo, SP, Brazil) and a soft-bristle toothbrush (Oral B; Oral B Laboratories, São Paulo, SP, Brazil), after every meal, three times a day. The participants watched a demonstration and had assisted training. Even so, patient's compliance with the cleaning protocol and plaque accumulation are dependent variables. For this reason, SEM micrographs were compared only within the same subject.

One month after denture insertion, two triangular fragments of about $3 \mathrm{~mm}$ in size were removed from a posterior palatal region of the denture bases using a sterile diamond disk. One fragment was removed from the right side (with Palaseal) and the other from the left side (without Palaseal). Three months after insertion, two other fragments were obtained as described. The donor areas were repaired after fragment removal.

In preparation for SEM analysis, the fragments were fixated in a $2 \%$ glutaraldehyde solution with sodium phosphate buffer and kept at $4^{\circ} \mathrm{C}$ for $48 \mathrm{~h}$. Thereafter, the specimens were rinsed in sodium phosphate buffer and sequentially dehydrated in an ascending ethanol series. Drying was completed and critical point was obtained in a device with continuous carbon dioxide flow (Critical point; Balzers Union, Liechteinstein). The specimens were mounted on stubs, sputter-coated with a 15-to-20 nanometerthick layer of gold (Sputtering SCD 030; Balzers Union) and examined with a scanning electron microscope (Stereoscan LEO 430; Zeiss-Leica, England). Micrographs were taken from selected areas in the central portion of each stub at X500, X5000 and X10000 magnifications and analyzed with regard to bacterial plaque formation on the glazed and non-glazed areas.

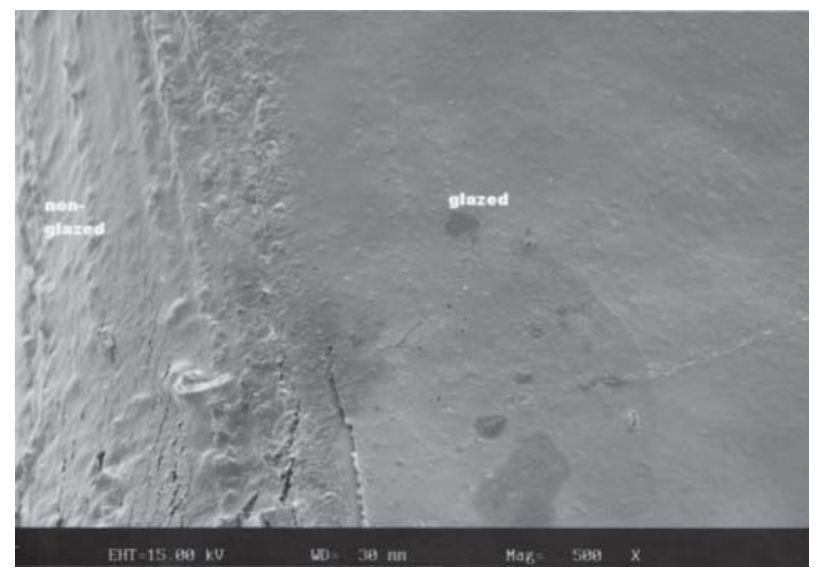

Figure 1. Boundary region between the glazed side and the nonglazed side, before denture insertion. Original magnification X500. 


\section{RESULTS}

Figures 2 to 6 are SEM micrographs illustrating plaque accumulation on both glazed and non-glazed sides of the fitting surface of the denture of a same patient, at 1- and 3-month evaluations. These images are representative of all 10 volunteers participating in this study, who showed similar results.

At 1 month, biofilm characteristics and composition on glazed and non-glazed specimens differed in all patients. As a rule, the glazed resin surface appeared covered by a thin layer of bacterial plaque, with small number of microorganisms (Fig. 2), while the non-glazed surfaces showed dense plaque formation, rich in microorganisms (Fig. 3).

At 3 months, the glazed surfaces were not

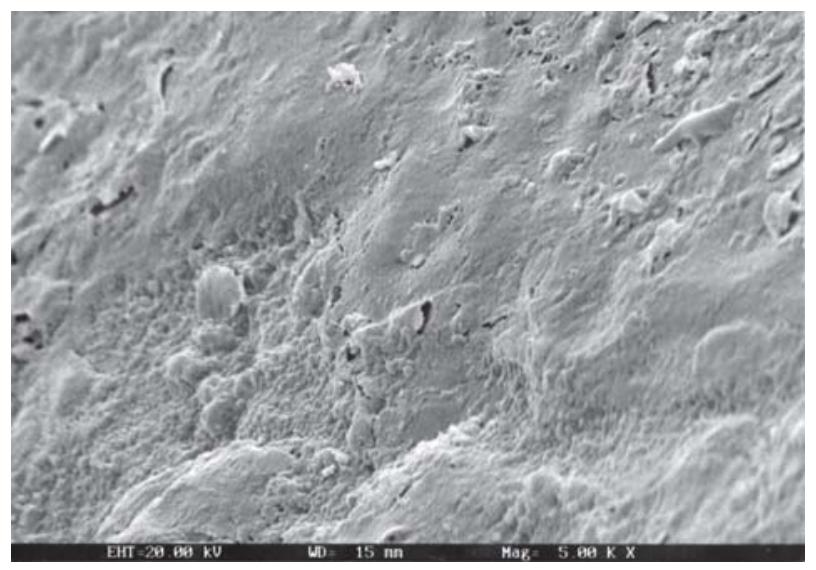

Figure 2. Glazed side (1 month). Denture plaque in an initial stage of colonization. Original magnification X5000.

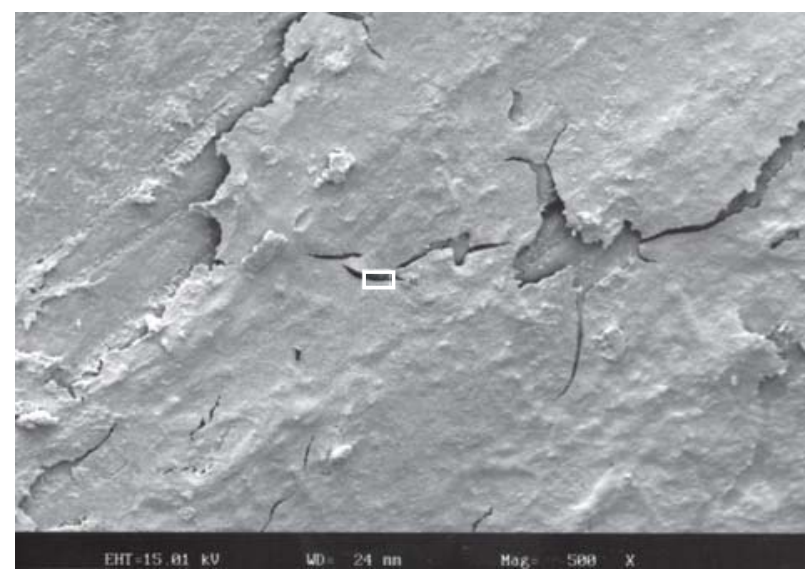

Figure 4. Glazed side (3 months). Glazed area with cracked appearance. The rectangle indicates a gap formed on the glaze layer. Original magnification X500. smooth and imperfections were found in some regions. Figure 4 shows an area in which the glaze layer was apparently cracked. Similar appearance was observed in all fragments treated with Palaseal, at this evaluation period. The glaze cracks acted as microniches that favored bacterial plaque retention. Figure 5 shows intense bacterial proliferation in the vicinities of the cracked area.

Generally, the non-glazed specimens presented a dense plaque film with characteristics of mature plaque (Fig. 6).

\section{DISCUSSION}

The aim of this study was to evaluate the real effect of denture surface glazing on bacterial plaque

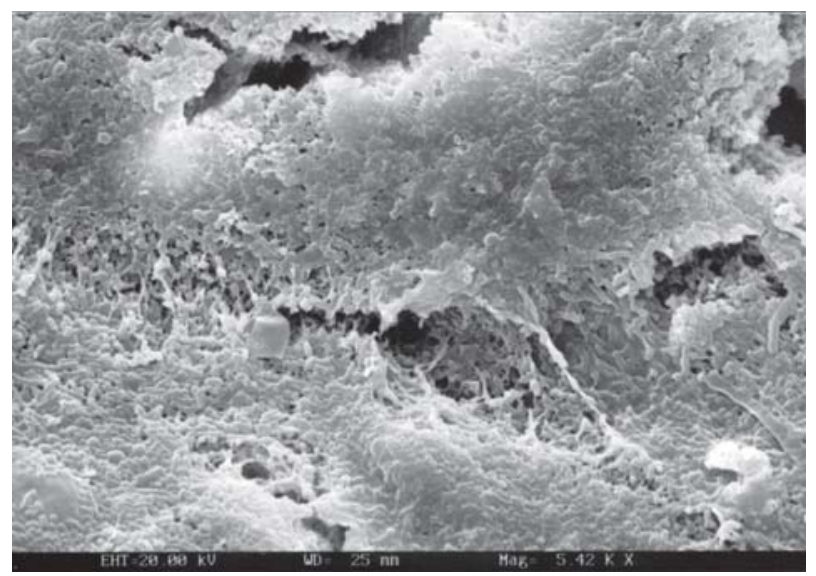

Figure 3. Non-glazed side (1 month). Intense colonization of the denture base's fitting surface by mature denture plaque. Original magnification X5000.

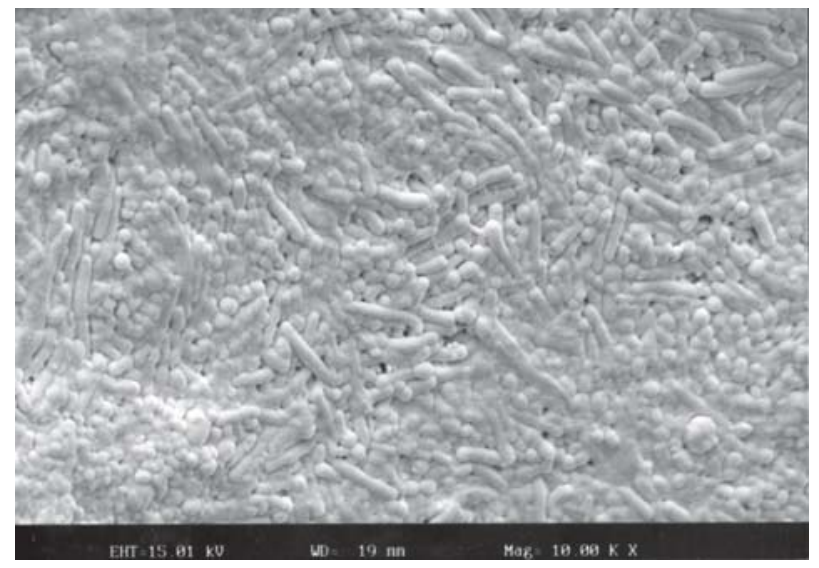

Figure 5. Glazed side (3 months). Greater magnification of the cracked area on Figure 4 (rectangle), showing bacterial outgrowth. Original magnification X10000. 


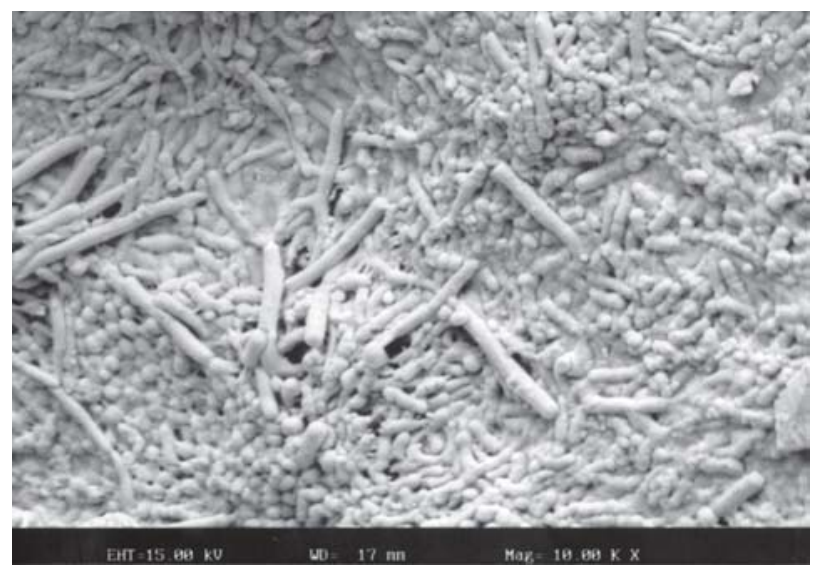

Figure 6. Non-glazed side (3 months). Dense plaque film. Original magnification X10000.

formation. An in vivo study using SEM analysis was designed because previous investigations on denture bacterial colonization $(8,9)$ have reported that plaque formed in vitro may differ from plaque formed in vivo with respect to colonizing microorganisms and adhesion to resin surface.

SEM observations showed differences in both composition and thickness of bacterial plaque, arrangement of microorganisms $(8,10)$ and resin surface appearance (11), comparing fragments extracted from glazed and non-glazed sides of the denture at each evaluation period. Comparison of SEM micrographs from different patients was not viable because of interindividual variations concerning plaque formation and denture cleansing, in spite of the standard instructions that all volunteers received.

Quantification of microorganisms on denture plaque was not the scope of this study, mainly because this method does not offer information about plaque composition. In addition, it has been reported that removal of microorganisms is easier on glazed surfaces (12), which could result in inaccurate microorganism counting.

One month after denture installation, plaque deposited on the non-glazed side consisted of a thick layer, with microorganisms disposed in a compact arrangement and presence of cocci, bacilli and filamentous bacteria, characteristic of a mature plaque. On the other hand, bacterial plaque on the glazed side consisted of a thinner layer with predominance of cocci, which indicates recent colonization and suggests that, although glazing does not prevent plaque accumulation it facilitates plaque removal.

Monsenego (13) also observed differences in the number of microorganisms present on glazed and nonglazed surfaces. However, from a quantitative point of view, this difference was considered insignificant, compared to the concentration of microorganisms on the fitting denture surface, which is in the order of $10^{4}$ $-10^{6}$ microorganisms $/ \mathrm{cm}^{2}$.

At 3 months, SEM images revealed intense bacterial colonization in the regions where the glazed layer was cracked or partially detached. According to Taylor et al. (14), a small increase in surface roughness has a significant effect on microbial adherence because the microscopic niches on resin surface lodge and protect the entrapped microorganisms. The pioneering species are easily established and colonization readily takes place because of the interbacterial affinity and the difficult of removal.

In this study, glaze cracks may have occurred due to the rigidity that the glaze layer acquires after polymerization. Szabó et al. $(15,16)$ have observed in vitro an increase of surface hardness and a decrease in the impact strength and transverse bending strength of resin surfaces coated with a surface glaze (Permalink; G.C. Dental Ind., Tokyo, Japan).

From the 1-month observations of glazed specimens, it may be assumed that had cracks not developed on the glaze layer, there would be significantly lesser bacterial colonization. However, SEM images after 3 months of denture installation showed that the glaze layer seemed to be detaching from resin surfaces in some regions. This may possibly be attributed the thinness, rigidity and brittleness of the glaze layer, which, upon exposure to oral environment, ends up cracking and being removed during mechanical oral hygiene procedures. These findings are not consistent with those of in vitro studies that reported enhancement of surface microhardness of glazed acrylic denture bases (17).

Clinically, smooth surfaces were noted immediately after treatment with Palaseal. Nevertheless, the clinical appearance of the glazed surfaces were not as smooth after 3 months of denture use, these findings being consistent with microscopic observations of wear or partial loss of glaze coating.

Dental laboratories are currently using denture glazes because of their ease of application, quick gloss conferred to the prosthesis and low cost. However, little 
is known about their limitations and real benefits. Patients receiving glazed dentures must be advised about the need of reapplication of the glaze and very well instructed not to neglect oral hygiene because the initial aspect of smoothness and brightness is not permanent. The benefits of glaze coating should be addressed and discussed with regard to all difficulties reported by the patients on their return for reapplication. Lack of periodic visits to the dental office to evaluate the need for glaze reapplication, however, can implicate in use of dentures with a porous glaze layer, which would provide niches for bacterial entrapment rather than achieving the major goal of glazing, that is producing a smooth surface to reduce plaque accumulation.

Denture surface glazing is temporary although beneficial. Studies have been carried out to develop a product with longer durability. Currently, glazes can be applied to definitive prostheses, albeit with limitations, but they are primarily indicated for temporary procedures, such as coating provisional dentures or acrylic orthodontic appliances (18).

To reduce microbial colonization, it would be interesting to incorporate bactericidal and fungicidal agents to the glaze, or to develop a glaze that, in addition to seal the surface irregularities, hindering mechanical adhesion, also had low surface energy to avoid chemical adhesion. Until such a product is not available, it is essential that patients are well instructed on self-care oral hygiene and use of products for denture cleansing, increasingly more efficient, to prevent bacterial plaque formation.

In conclusion, the findings of this clinical experiment showed that although glazing denture's fitting surface did not prevent bacterial colonization, it favored plaque removal while the glaze layer was intact (1-month evaluation). After three months of denture use, glaze cracks developed and created microretentive areas that increased plaque accumulation.

\section{RESUMO}

Este estudo avaliou, in vivo, a eficiência de um glaze para bases protéticas (Palaseal) em modificar a colonização microbiana de próteses. Dez indivíduos foram selecionados e receberam próteses removíveis maxilares provisórias, com cobertura total do palato em acrílico. A metade direita da superfície interna das bases protéticas foi glazeada com Palaseal enquanto a outra metade ficou sem glaze. Um mês após a instalação, dois fragmentos foram removidos de todas as bases protéticas (um do lado glazeado, outro do lado não glazeado). Estas amostras foram preparadas e examinadas em microscopia eletrônica de varredura. Três meses após a instalação, outros fragmentos foram removidos e analisados. Observações microscópicas após 1 mês revelaram que, para todos os pacientes, a placa era menos espessa do lado tratado, em comparação ao lado não-tratado. Entretanto, observações aos 3 meses mostraram que áreas do glaze haviam trincado e, tanto o lado glazeado como o lado não-glazeado estavam cobertos por uma densa camada de placa bacteriana. Os achados desse estudo clínico demonstraram que o glazeamento da superfície interna da prótese não impediu a colonização bacteriana, mas favoreceu a remoção da placa enquanto a camada de glaze esteve intacta. Decorridos 3 meses, o glaze sofreu trincas, criando áreas de microretenção que aumentaram o acúmulo de placa.

\section{ACKNOWLEDGEMENTS}

We would like to thank Dr. Rui Gastaldone Jaegger (Associate Professor) and Nilton Azambuja Junior (Postgraduate Dental Student) for the SEM images.

\section{REFERENCES}

1. Kulak-Ozkan Y, Kazazoglu E, Arikan A. Oral hygiene habits, denture cleanliness, presence of yeasts and stomatitis in elderly people. J Oral Rehabil 2002;29:300-304.

2. Webb BC, Thomas CJ, Willcox MDP, Harty DWS, Knox KW. Candida-associated denture stomatitis. Aetiology and management: A review. Aust Dent J 1998;43:45-50.

3. Pires FR, Santos EBD, Bonan PRF, De Almeida OP, Lopes MA. Denture stomatitis and salivary Candida in Brazilian edentulous patients. J Oral Rehabil 2002;29:1115-1119.

4. Iacopino AM, Wathen WF. Oral candidal infection and denture stomatitis: a comprehensive review. J Am Dent Assoc 1992;123;46-51.

5. Jagger DC, Al-Akhazami L, Harrison A, Rees JS. The effectiveness of seven denture cleansers on tea stain removal from PMMA acrylic resin. Int J Prosthodont 2002;15:549552.

6. Davenport JC, Basker RM, Heath JR, Ralph JP. Color atlas of removable partial dentures. 2nd ed. London: Mosby-Wolfe; 1994.

7. Nikawa H, Hamada T, Yamamoto T. Denture plaque- past and recent concerns. J Dent 1998;26:299-304.

8. Gwinnett AJ, Caputo L. The effectiveness of ultrasonic denture cleaning: a scanning electron microscope study. J Prosthet Dent 1983;50:20-25.

9. Radford DR, Challacombe SJ, Walter JD. Adherence of phenotypically switched Candida albicans to denture base materials. Int J Prosthod 1998;11:75-81.

10. Catalán A, Herrera R, Martinez A. Denture plaque and palatal mucosa in denture stomatitis: scanning electron microscopic and microbiologic study. J Prosthet Dent 1987;57:581-591.

11. Kulak Y, Arikan A, Albak S, Okar I, Kazazoglu E. Scanning electron microscopic examination of different cleaners: surface contaminant removal from dentures. J Oral Rehabil 1997;24:209-215.

12. Budtz-Jorgensen E, Kaaber S. Clinical effects of glazing denture acrylic resin bases using an ultraviolet curing method. Scand J Dent Res 1986;94:569-574. 
13. Monsenego P. Presence of microorganisms on the fitting denture complete suface: study in vivo. J Oral Rehabil 2000; 27:708-713.

14. Taylor RL, Verran J, Lees GC, Ward AJP. The influence of substratum topography on bacterial adhesion to polymethyl methacrylate. J Mat Sci Mater Med 1998;123:17-22.

15. Szabó G, Valderhaug J, Ruyter IE. Some properties of a denture acrylic coating. Acta Odont Scand 1985;43:249-256.
16. Szabó G, Stafford GD, Huggett R. Some mechanical properties of denture-base polymers treated with an ultraviolet lightactivated coating material. J Dent 1987;15:261-265.

17. Emmanouil JK, Kavouras P, Kehagias T. The effect of photoactivated glazes on the microhardness of acrylic baseplate resins. J Dent 2002;30:7-10.

18. Mantzikos T, Epstein M. Interior surface sealant for acrylic appliances. J Clin Orthod 1998;32:152-153.

Accepted October 10, 2004 